Electronic scientific and practical journal

\title{
INTELLECTUALIZATION OF LOGISTICS AND SUPPLY CHAIN MANAGEMENT
}

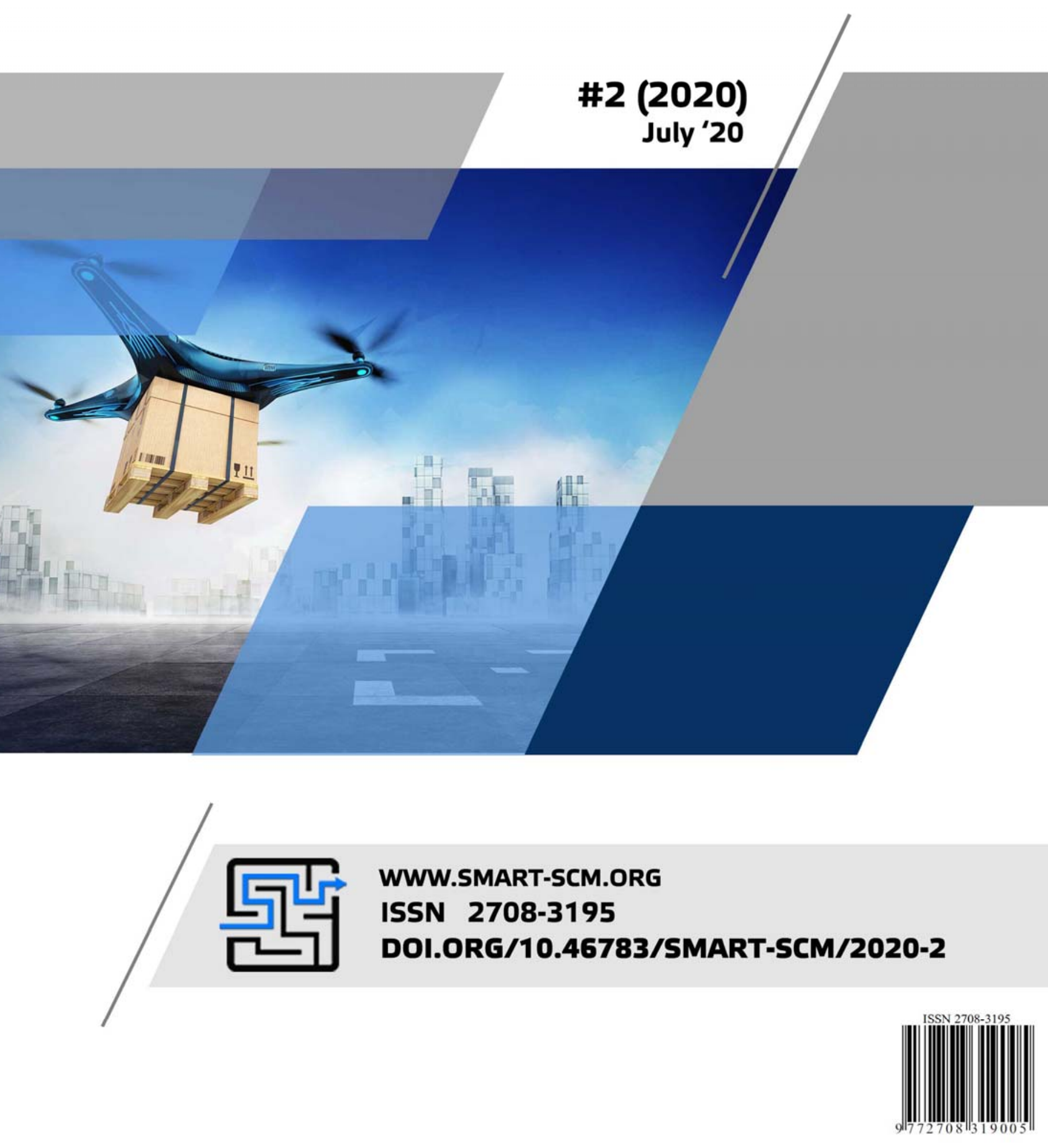




\section{Electronic scientific and practical collection
INTELLECTUALIZATION OF LOGISTICS
AND SUPPLY CHAIN MANAGEMENT}

Electronic scientific and practical publication in economic sciences

ISSN 2708-3195

DOl: https://doi.org/10.46783/smart-scm/2020-2

Released 6 times a year

№ 2 (2020)

July 2020

Kyiv - 2020 
Founder: Viold Limited Liability Company

Editor in Chief:

Deputy editors-in-chief:

Technical editor:

Executive Secretary:
Hryhorak M. Yu. - Doctor of Economics, Ass. Professor.

Koulyk V. A. - PhD (Economics), Professor.

Marchuk V. Ye. - Doctor of Tech. Sci., Ass. Professor.

Harmash O. M. - PhD (Economics), Ass. Professor.

Davidenko V. V. - PhD (Economics), Ass. Professor.

\section{Members of the Editorial Board:}

SWIEKATOWSKI Ryszard - Doctor of Economics, Professor (Poland);

POSTAN M. Ya. - Doctor of Economics, Professor;

TRUSHKINA N. V. - PhD (Economics), Corresponding Member of the Academy;

KOLOSOK V. M. - Doctor of Economics, Professor;

ILCHENKO N. B. - Doctor of Economics, Ass. Professor;

SOLOMON D. I. - Doctor of Economics, Professor (Moldova);

ALKEMA V. H. - Doctor of Economics, Professor;

Henryk DŹWIGOŁ - PhD (Economics), Professor (Poland);

SUMETS O. M. - Doctor of Economics, Ass. Professor;

STRELCOVÁ Stanislava - PhD (Economics), Ass. Professor, (Slovakia);

RISTVEJ Jozef (Mr.) PhD (Economics), Professor, (Slovakia);

ZAMIAR Zenon - Doctor of Economics, Professor, (Poland);

SMERICHEVSKA S. V. - Doctor of Economics, Professor;

GRITSENKO S. I. - Doctor of Economics, Professor;

KARPENKO O. O. - Doctor of Economics, Professor;

PATKOVSKYI S. A. - Business practitioner.

The electronic scientific and practical journal is registered in international scientometric data bases, repositories and search engines. The main characteristic of the edition is the index of scientometric data bases, which reflects the importance and effectiveness of scientific publications using indicators such as quotation index, h-index and factor impact (the number of quotations within two years after publishing).

In 2020, the International Center for Periodicals (ISSN International Center, Paris) included the Electronic Scientific and Practical Edition "Intellectualization of Supply Chain Management" in the international register of periodicals and provided it with a numerical code of international identification: ISSN 2708-3195 (Online).

Recommended for dissemination on the Internet by the Academic Council of the Department of Logistics NAU (No. 7 of February 26, 2020). Released 6 times a year. Editions references are required. The view of the editorial board does not always coincide with that of the authors.

t.me/smart_scm facebook.com/Smart.SCM.org twitter.com/ScmSmart

DOI: https://doi.org/10.46783/smart-scm/2020-2 e-mail: support@smart-scm.org тел.: (063) 593-30-41

https://smart-scm.org 


\section{Contents}

INTRODUCTION

GRITSENKO S.I. Doctor of Economics, Professor, Professor of Logistics Department National Aviation University (Ukraine), KARPUN O.V. PhD of Economics, Associate Professor, Associate Professor of Logistics Department National Aviation University (Ukraine)

CREATION OF AVIATION TRANSPORT AND LOGISTIC CLUSTERS NETWORK

$7-15$

KOSTYUCHENKO L.V.PhD (Economics), Associate Professor, Associate Professor of Logistics Department National Aviation University (Ukraine), KOSTIUCHENKO A.V. lieutenant-colonel Armed Forces of Ukraine, Kyiv, (Ukraine)

THE LOGISTICAL SUPPORT SYSTEM ELEMENTS FOR THE PREPAREDNESS FOR MILITARY OPERATIONS

MARCHUK V.Ye. Doctor of Engineering, Associate Professor, Professor of Logistics Department National Aviation University (Ukraine), HARMASH O.M. PhD (Economics), Associate Professor, Associate Professor of Logistics Department National Aviation University (Ukraine), OVDIIENKO O.V. PhD student, Assistant at Logistic Department at National Aviation University (Ukraine)

WORLD TRENDS IN WAREHOUSING LOGISTICS

PATKOVSKYI Sergii Business practitioner; Business development manager, emerging markets Kuehne + Nagel Inc., Chicago, IL (USA), LYTVYNENKO S.L. PhD (Economics), Associate Professor, Associate Professor of International Economics Department National Aviation University (Ukraine) THE WAYS OF SUPPLY CHAIN RESPONSIVENESS INCREASE AT TIME OF PORT INFRASTRUCTURE AND TRANSPORTATION ASSETS PRODUCTIVITY DISRUPTION

POPOVYCHENKO I.V. Doctor of Economic, Professor, Head of Economics and Entrepreneurship Department State Higher Educational Establishment "Prydniprovs'ka State Academy of Civil Engineering and Architecture", Dnipro, (Ukraine), SPIRIDONOVA K.O. PhD (Economics), Associate Professor, Associate Professor of Economics and Entrepreneurship Department State Higher Educational Establishment "Prydniprovs'ka State Academy of Civil Engineering and Architecture", Dnipro, (Ukraine) APPLICATION OF FUNCTION COST ANALYSIS AND NETWORK SCHEDULING IN LOGISTICS COSTMANAGEMENT 
KOLOSOK V.M. Doctor of Economic, Professor, Head of the Department of Transport Management and Logistics Department Priazovsky State Technical University (Ukraine), LAZAREVSKA Yulianna. PhD student Donetsk National Technical University (Ukraine) EFFICIENCY OF DIGITAL COMMUNICATIONS IN THE LOGISTICS BUSINESS: EVALUATION INDICATORS

CHORNOPYSKA N.V. PhD (Economics), Associate Professor, Associate Professor at department marketing and logistics at Lviv Polytechnic National University (Ukraine), BOLIBRUKH L.I. Student at department marketing and logistics at Lviv Polytechnic National University (Ukraine)

THE INFLUENCE OF THE COVID-19 CRISIS ON THE FORMATION OF LOGISTICS

QUALITY

KOPISHYNSKA K. O. PhD (Economics), Senior Lecturer of Department of Management, National Technical University of Ukrainen "Igor Sikorsky Kyiv Polytechnic Institute" (Ukraine)

CURRENT STATE AND PROSPECTS OF DIGITAL TRANSFORMATION OF THE TRANSPORT AND LOGISTICS SECTOR OF UKRAINE

HRYHORAK M. Yu. ., Doctor of Science in Economics, Associate Professor, Head of Logistics Department of National Aviation University (Ukraine), KARPENKO 0.0., Doctor of Science in Economics, Professor, Professor by Water Transport Management and Economics Department, State University of Infrastructure and Technologies (Ukraine), SEMERIAHINA M. M., Senior Lecturer of Logistics Department of National Aviation University (Ukraine)

FORMATION OF THE MULTIMODAL TRANSPORT ECOSYSTEM IN UKRAINE

The History of Science.

MIROTIN Leonid Borysovych - the Doctor of Technical Sciences, Professor 
UDC 005.6: 656

DOI: https://doi.org/10.46783/smart-scm/2020-2-7

JEL Classification: C 52; D 11; E 21; L 89; M 31; R 40.

Received: 30 July 2020

Chornopyska N.V. PhD (Economics), Associate Professor, Associate Professor at department marketing and logistics at Lviv Polytechnic National University (Ukraine)

ORCID - 0000-0001-9074-7607

Researcher ID -

Scopus author id: -

Bolibrukh L.I. Student at department marketing and logistics at Lviv Polytechnic National University (Ukraine)

ORCID - 0000-0003-2407-6838

Researcher ID -

Scopus author id: -

\section{THE INFLUENCE OF THE COVID-19 CRISIS ON THE FORMATION OF LOGISTICS QUALITY}

Natalyia Chornopyska, Lidiia Bolibrukh. "The influence of the COVID-19 crisis on the formation of logistics quality". Relevance of research. COVID-19 crisis has led to an unequal consequence. Some industries collapsed, some - reached the top of their development. Thus, E-commerce passed a three-year path during the pandemic. Such rapid growth has led to logistical reconsideration of the e-commerce market, which raises the issue of logistics services. Despite the presence of many methodological and applied developments, the issue of measurability of logistics quality, a set of evaluation criteria for the quality of logistics services remains debatable, and due to recent events caused by the COVID-19 pandemic, suitability of applied evaluation criteria to variable environmental requirements. Thus, the problem of market value transformation of logistics needs further research.

The purpose of the study is to further develop guidelines for assessing the quality of logistics in view of current post-COVID-19 challenges. For this goal achievement it was necessary to solve the following tasks: to conduct marketing research on the quality of logistics of e-commerce in quarantine and, on this basis, to make conclusions about the transformation of the value of logistics and B2C market, which will be reflected in a set of evaluation criteria for logistics quality.

Methods: express survey of 240 e-consumers in 19 regions of Ukraine during April-May 2020 on the basis of an online-questionnaire created on Google Forms platform and shared on social networks like Facebook, Instagram, Telegram and Viber.

Conclusions and value added. The results of the study have showed that in modern conditions the formation of the quality of logistics in the B2C market is influenced by the following criteria: flexibility, timeliness, completeness, wholeness, security and E2E-interaction. It is important for consumers to be able to independently choose additional delivery functions - place, time, delivery period, method of payment, which indicates the need to develop flexibility in the services of logistics operators. The modern consumer values his time, respectively, so the logistics service provider doesn 't have the right to make a mistake in completing the order or improper 
storage of goods. The transformation of the value of logistics services, in the post-COVID-19 conditions, concerns online interaction and speed of data exchange with the logistics service provider: contactless technologies, gadgets and applications that provide seamless online work, regardless of location. Online interaction, in particular online shopping, according to the study, attracts them with its simplicity, the ability to compare prices on different platforms, the availability of a wide range of goods and saving time. Thus, the value of the benefits of digitalization increases. Those logistics providers that are more technologically advanced have a significant competitive advantage. E2E determine the value.

Keywords: COVID-19 crisis; e-commerce market; online shopping; e-consumer; quality of logistics; logistics provider; methods for evaluation the quality of logistics; evaluation criteria; value; E2E-interaction; logistics services

Наталія Чорнописька, Лідія Болібрух. «Вплив кризи COVID-19 на формування якості логістики». Актуальність дослідження. Криза COVID-19 розподілилася нерівномірно. Окремі галузі занепали, інші - досягли свого піку. Так, е-сотmеrсе за період пандемії пройшла трьохрічний шлях. Такий стрімкий ріст призвів до перегляду логістичної складової ринку е-соттеrсе, що актуалізує питання якості логістичних послуг та дослідження проблеми трансформачії чінності логістики з погляду ринку.

Метою дослідження $\epsilon$ подальший розвиток методичних положень оцінювання якості логістики з огляду сучасних викликів Post-COVID-19. Для досягнення поставленої мети необхідно було вирішити такі завдання: провести маркетингове дослідження якості логістики інтернет-торгівлі в умовах карантину і, на чій основі, зробити висновки відносно трансформації чінності логістики та ринку В2С, що знайде своє відображення в наборі оцінних критеріїв якості логістики.

Методика дослідження: експрес-опитування 240 е-споживачів у 19 областях України протягом квітня-травня 2020 р. на підставі створеної за допомогою Google Forms та розповсюдженої у таких сочіальних мережах як Facebook, Instagram, Telegram ma Viber анкети.

Висновки. Як показали результати проведеного дослідження, в сучасних умовах на формування якості логістики на ринку В2С впливають такі критерії: гнучкість, вчасність, комплектність, чілісність, безпечність та E2E-взаємодія. Трансформачія чінності логістичної послуги, в роst-COVID19 середовищі, стосується он-лайн взаємодії та швидкості обміну даними з постачальником логістичної послуги: безконтактні технології, гаджети та додатки, що забезпечують безперебійну он-лайн роботу, незалежно від місия знаходження. Он-лайн взаємодія, зокрема он-лайн покупки, за результатами дослідження, приваблюють їх своєю простотою, можливістю порівнювати ціни на різних платформах, доступністю широкого асортименту товарів та економією часу. Підвищення рівня діджиталізачії спровокувало зміну фокусу чінності логістичної послуги для споживачів, тому власна мобільність та можливість економії часу для сучасного клієнта стали пріоритетними. Отже, збільшується цінність переваг, що дає діджиталізація. Ті логістичні оператори, які є більш просунутими технологічно, мають суттєву конкурентну перевагу. Е2Е визначає цінність.

Ключові слова: криза COVID-19; ринок е-commerce; інтернет-покупки; е-споживач; якість логістики; логістичний оператор; методи оцінки якості логістики; оцінні критерії; цінність; Е2Евзаємодія; логістичні послуги.

Наталия Чорнопыська, Лидия Болибрух. «Влияние кризиса COVID-19 на формирование качества логистики». Актуальность исследования. Кризис COVID-19 распредилился неравномерно. Некоторые отросли упали, другие - достигли своего пика. Кпримеру, е-соттегсе за период пандемии прошла путь на три года вперед. Такой стремительный рост привел к пересмотру логистической составляющей рынка е-соттеrсе, что актуализирует вопрос качества логистических услуг, исследования проблемы трансформации ценности логистики с точки зрения рынка.

Целью исследования является дальнейшее развитие методических положений оченки качества логистики с учетом современных вызовов Post- COVID-19. Для достижения поставленной чели необходимо было решить следующие задачи: провести маркетинговые исследования качества логистики интернет-торговли в условиях карантина и на этой основе сделать выводы 
относительно трансформации ченности логистики и рынка B2C, что найдет свое отражение в наборе оченочных критериев качества логистики.

Методика исследования: экспресс-опрос 240 е-потребителей в 19 областях Украины в течение апреля-мая 2020 на основании созданной с помощью Google Forms и распространенной в таких социальных сетях как Facebook, Instagram, Telegram и Viber анкеты.

Выводы. Как показали результаты проведенного исследования в современных условиях на формирование качества логистики на рынке В2С влияют следующие критерии: гибкость, своевременность, комплектность, челостность, безопасность и Е2Е-взаимодействие. Трансформация ченности логистической услуги, в роst-COVID-19 условиях, касается он-лайн взаимодействия и скорости обмена данными с поставщиком логистической услуги: бесконтактные технологии, гаджеты и приложения, обеспечивающие бесперебойную онлайн работу, независимо от места нахождения. Онлайн-взаимодействие, в том числе он-лайн покупки, по результатам исследования, привлекают их своей простотой, возможностью сравнивать иены на разных платформах, доступностью широкого ассортимента товаров и экономией времени. Повышение уровня диджитализации спровоцировало изменение фокуса ченности логистической услуги для потребителей, так собственная мобильность и возможность экономии времени для современного клиента стали приоритетными. Следовательно, увеличивается ченность преимуществ, которые дает диджитализачия. Те логистические провайдеры, которые являются более продвинутыми технологически, имеют существенное конкурентное преимущество. E2E определяет ченность.

Ключевые слова: кризис COVID-19; рынок е-commerce; интернет-покупки; е-потребитель; качество логистики; логистический провайдер; методы оценки качества логистики; оценочные критерии; ценность; Е2Е-взаимодействий; логистические услуги

Introduction. The world was gripped by an unpredictable coronavirus pandemic that forced quarantine restrictions on more than a third of the world's population. Such drastic actions have led to unpredictable consequences for the economy and development of many countries at the global level, as well as the purchasing power of the population and its mobility. In particular, the pandemic has a great impact on the logistics industry, which is now demonstrating its flexibility and importance in the general state of countries' lives. In such extreme conditions, humanitarian logistics has become critical [2].

COVID-19 crisis wasn't smooth. Some industries collapsed, some - reached the top of their development. The COVID-19 pandemic has led to the accelerated growth of e-commerce. Analyzing the e-commerce market in Ukraine, it is tracing the rapid development of the industry in recent years. In particular, in 2018, the Ukrainian market was ranked second in Europe in terms of growth rate (30\%), in 2019 it was 17\%, and, according to preliminary forecasts, in 2020 $15 \%$ [3]. However, an external factor became unpredictable - the coronavirus pandemic, which stimulated a sharp increase in demand for online shopping. In April 2020 the Ecommerce market reached the mark of 2023 (within 8 weeks the path has been covered in 3 years) [4]. Such rapid growth has become a serious challenge for logistics, which has highlighted the problem of quality logistics services.

The works of such founders of logistics science as Lambert D., Bauersachs D., Pfoll H. and domestic classics - Krykavsky E, Grygorak $M$., especially their latest ones, are devoted to theoretical and applied issues of logistics quality $[5,6]$. Logistics quality assessment methodologies have been developed by leading think tanks and consulting centers, including the World Bank, which calculates and publishes the Logistics Efficiency Index (LPI), where quality is one of the six subindices [7]. The following scientists made a significant contribution to the coverage of the method of assessing the quality of enterprise logistics: Meffert G. [8], Parasuraman A. [9], Bruhn M. [10], Voźniak J. [11], Fraś J. [12], Nakonechna. T., Gryniv N. [13].

At the same time, despite the availability of many methodological and applied works, 
the issue of logistics quality assessment, a set of evaluation criteria for the quality of logistics services is still debatable (there is no united approach or view, lack of coherence and formalization), and due to recent developments and the question of the suitability of the applied evaluation criteria for the changing requirements of the environment. Thus, the problem of market value transformation of logistics needs further research.

\section{The purpose and objectives of the} study. The purpose of the study is to further develop guidelines for assessing the quality of logistics in view of current post-COVID-19 challenges. For the achievement of this goal it was necessary to solve the following tasks: to conduct marketing research on the quality of logistics of e-commerce in quarantine and, on its basis, to make conclusions about the transformation of the value of logistics and B2C market, which will be reflected in a set of evaluation criteria for logistics quality.

Primary materials and results. The marketing research was conducted in AprilMay 2020 and included an express survey based on an online questionnaire created on Google Forms platform and shared on social networks like Facebook, Instagram, Telegram and Viber, which served as the main research tool. The research methodology provided details of objectives, search questions and hypotheses (parameters) that should be defined (Table 1).

Objectives, search questions, hypotheses (parameters) of study

\begin{tabular}{|c|c|c|}
\hline $\begin{array}{l}\text { Objectives of the } \\
\text { study }\end{array}$ & Search questions & Hypotheses (parameters) \\
\hline \multirow{5}{*}{$\begin{array}{l}\text { 1. To assess the } \\
\text { demand in the } \\
\text { online format in } \\
\text { the Ukrainian } \\
\text { market and to } \\
\text { determine the } \\
\text { impact of } \\
\text { quarantine on } \\
\text { the online } \\
\text { shopping } \\
\text { intensification. }\end{array}$} & $\begin{array}{l}\text { How often do consumers } \\
\text { shop online? }\end{array}$ & \multirow{3}{*}{$\begin{array}{l}\text { In the structure of trade, online sales } \\
\text { are still inferior to offline sales, but } \\
\text { there is a significant increase in } \\
\text { demand for online services during } \\
\text { quarantine restrictions. }\end{array}$} \\
\hline & $\begin{array}{l}\text { Did consumers make online } \\
\text { purchases during quarantine? }\end{array}$ & \\
\hline & $\begin{array}{c}\text { Will consumer buying } \\
\text { behavior change after } \\
\text { quarantine? }\end{array}$ & \\
\hline & $\begin{array}{c}\text { What types of factors affect } \\
\text { online shopping? }\end{array}$ & $\begin{array}{l}\text { The main advantage of online } \\
\text { shopping is a wide range of hard-to- } \\
\text { reach products and time savings. }\end{array}$ \\
\hline & $\begin{array}{l}\text { What goods are in demand } \\
\text { during quarantine? }\end{array}$ & $\begin{array}{l}\text { The largest share of online shopping } \\
\text { structure is accounted for by } \\
\text { expensive appliances, clothing and } \\
\text { restaurant meals, but during } \\
\text { quarantine the demand for food and } \\
\text { household chemicals rose sharply. }\end{array}$ \\
\hline \multirow{4}{*}{$\begin{array}{l}\text { 2. To identify the } \\
\text { main logistics } \\
\text { operators that } \\
\text { deliver online } \\
\text { stores goods, } \\
\text { method of } \\
\text { delivery and } \\
\text { determine the } \\
\text { level of quality of } \\
\text { logistics } \\
\text { services. }\end{array}$} & $\begin{array}{l}\text { What platforms are used for } \\
\text { goods ordering? }\end{array}$ & $\begin{array}{l}\text { Most often, orders are placed on } \\
\text { specialized online trading platforms } \\
\text { or social networks. }\end{array}$ \\
\hline & $\begin{array}{c}\text { How was the delivery carried } \\
\text { out? }\end{array}$ & $\begin{array}{l}\text { The service of goods delivery to the } \\
\text { post office is popular, but on } \\
\text { quarantine conditions consumers } \\
\text { more often use courier delivery. }\end{array}$ \\
\hline & $\begin{array}{l}\text { Which postal operators are } \\
\text { serving e-commerce market? }\end{array}$ & \multirow{2}{*}{$\begin{array}{l}\text { "Nova Poshta" has the largest } \\
\text { volume of deliveries to the branch } \\
\text { and via courier in Ukraine, but } \\
\text { "Ukrposhta" makes international } \\
\text { shipments. }\end{array}$} \\
\hline & $\begin{array}{c}\text { Which courier services are the } \\
\text { most popular? }\end{array}$ & \\
\hline
\end{tabular}


End of Table 1

\begin{tabular}{|c|c|c|}
\hline & $\begin{array}{c}\text { What evaluation criteria can } \\
\text { be used to determine the } \\
\text { quality of logistics services of } \\
\text { a postal operator or courier } \\
\text { service? }\end{array}$ & $\begin{array}{c}\text { It is assumed that the most } \\
\text { important for buyers are the } \\
\text { timeliness of delivery, its } \\
\text { completeness and flexibility, but in } \\
\text { quarantine, these criteria may } \\
\text { change. }\end{array}$ \\
\hline \multirow{5}{*}{$\begin{array}{l}\text { 3. To clarify the } \\
\text { profile of the } \\
\text { target audience, } \\
\text { whether it is } \\
\text { possible to } \\
\text { change the } \\
\text { structure of } \\
\text { consumers after } \\
\text { quarantine. }\end{array}$} & Sex? & \multirow{5}{*}{$\begin{array}{l}\text { Most often, online stores orders are } \\
\text { made by progressive young people } \\
\text { under } 25 \text { who live in large cities, } \\
\text { study or work there. Most consumers } \\
\text { are women. In the fast life pace, } \\
\text { orders are used to by smartphones. }\end{array}$} \\
\hline & Age? & \\
\hline & Activity? & \\
\hline & Type of settlement? & \\
\hline & $\begin{array}{c}\text { What electronic device do you } \\
\text { use to make online } \\
\text { purchases? }\end{array}$ & \\
\hline
\end{tabular}

Complied by authors.

Questionnaire questions were developed based on the search questions transformation.

The survey started at the end of April 2020 and covered 240 respondents, the breadth of the geography of the study - 19 regions, of which the largest number of participants are from Lviv (61\%), Kyiv (17.4\%) and Ivano-Frankivsk (8.3\%) regions. Geographical coverage and profile of the target audience of the study are presented in Fig.1a-1b.

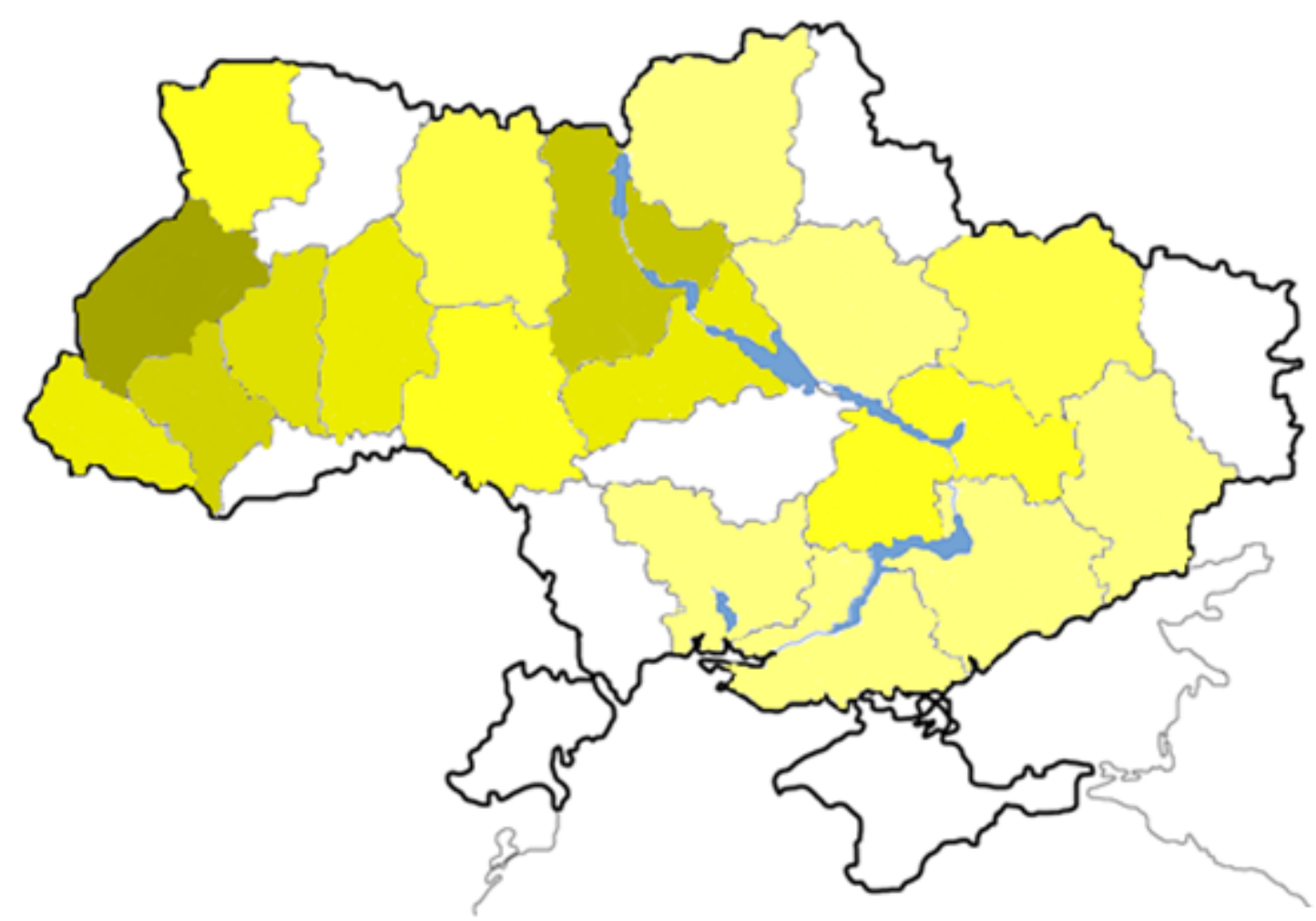

Figure 1a. Geographical coverage and profile of the target audience of the study 


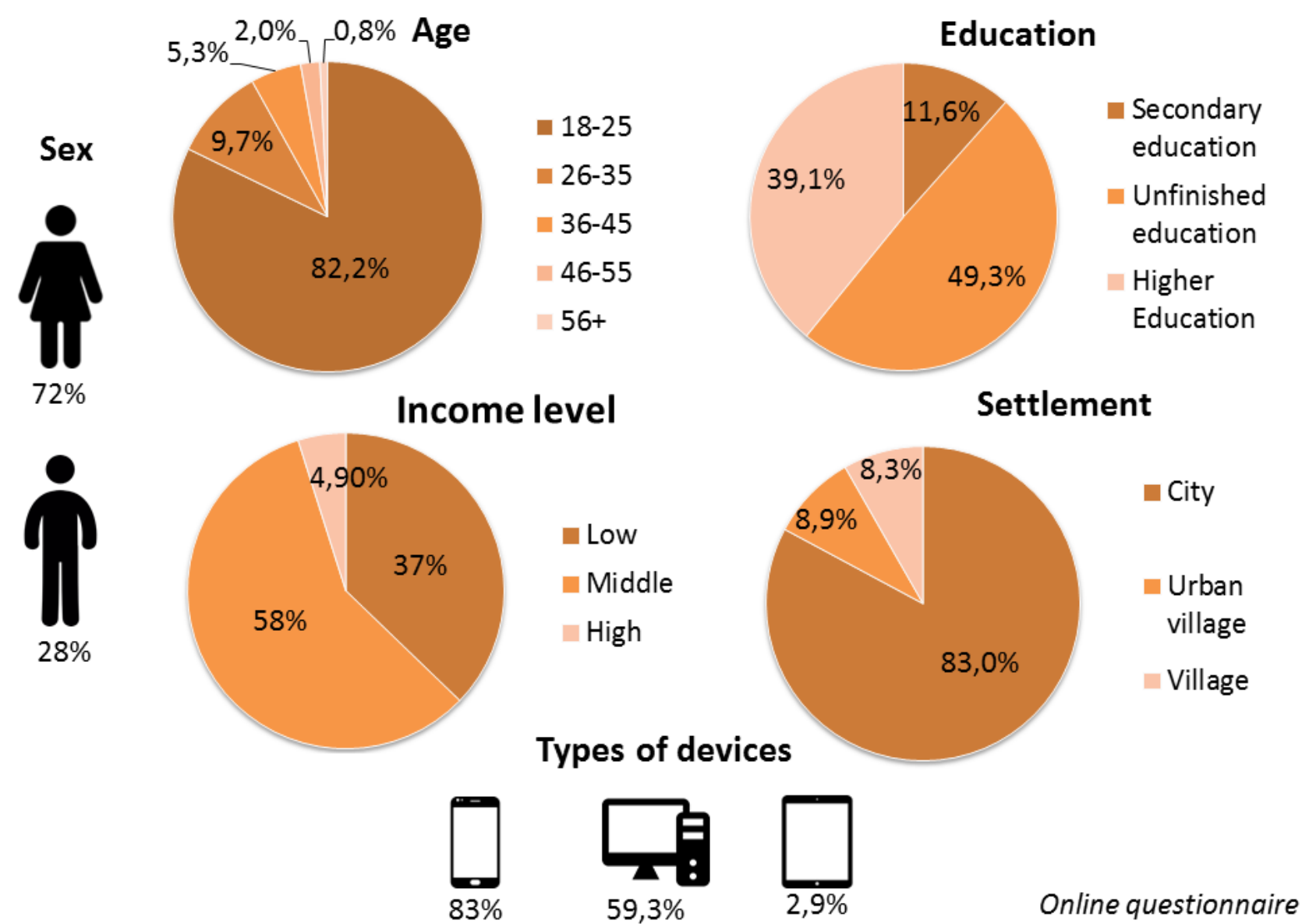

Figure 1b. Geographical coverage and profile of the target audience of the study Complied and calculated by authors based on results of provided survey

The profile of the target audience of online commerce confirms that the majority of respondents are women aged 18 to 25 who study or work and have an average income. Virtually everyone lives in cities where more logistics operators are available, and uses smartphones (83\%) and computers (59.3\%) for online shopping.

An infographic of the survey results on the demand for online shopping in the Ukrainian market during quarantine is presented in Fig.2. According to it we can conclude that online shopping in Ukraine is quite popular (58.3\%). Despite the fact that online shopping has entered the domestic market quite recently, today it has its target audience, which uses such services both under normal conditions and during quarantine restrictions (19.6\%). Now we can see some growth in demand for online products $(76.6 \%)$, but according to most respondents, their shopping habits will not change after quarantine, and only $20.6 \%$ are convinced that they will use online services more often. 


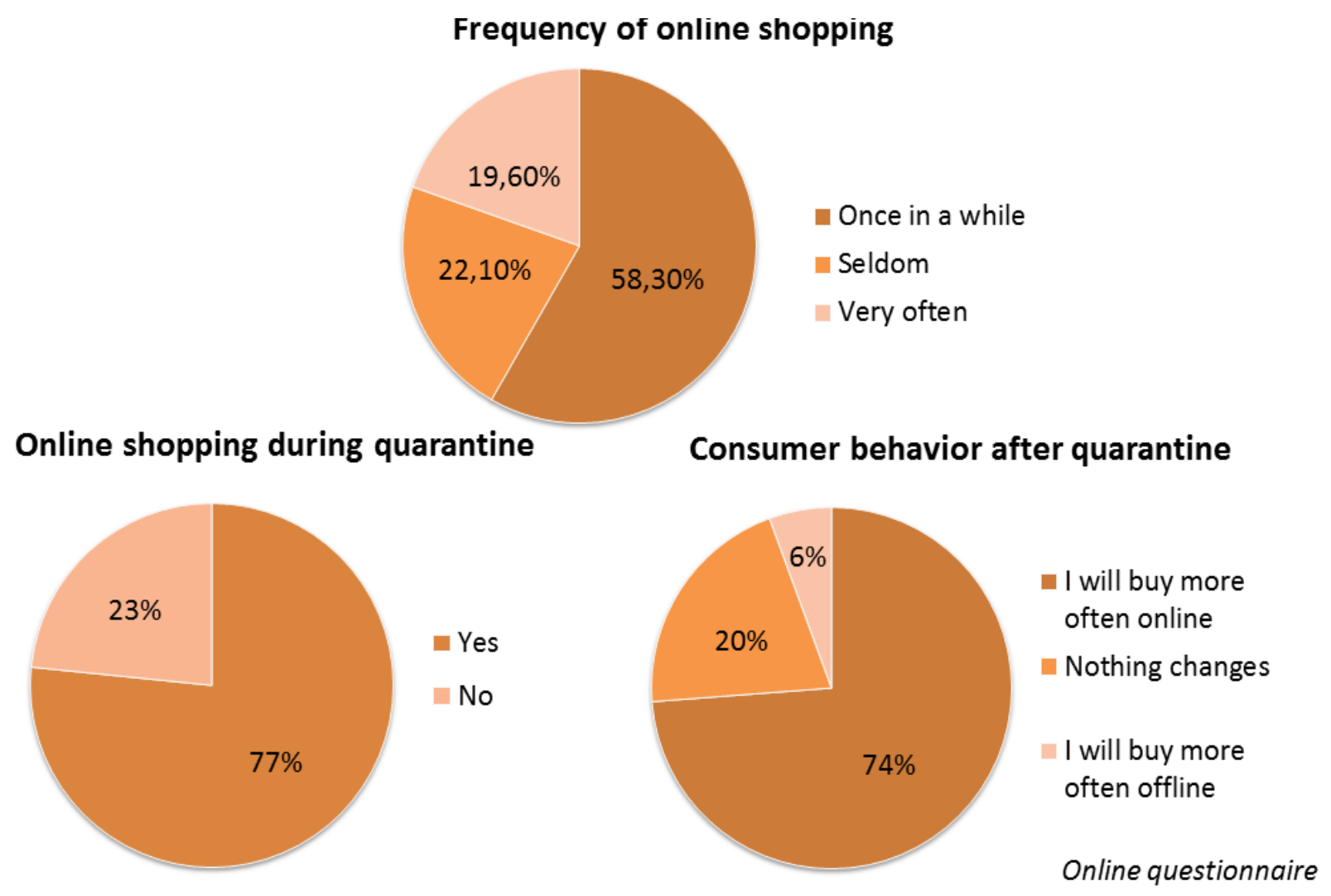

Figure 2. Buying behavior during quarantine

Complied and calculated by authors based on results of provided survey

Online shopping provides those consumer values that are difficult for ordinary offline stores to provide, and what are the most valuable for shoppers (Fig. 3). It was assumed that in the conditions of quarantine unpredictable circumstances (restriction of movement of people, reduction of product range due to mass purchase) will become a significant factor influencing demand, but respondents note the following criteria: convenience of ordering, simple process of ordering products $(67.2 \%)$; possibility to compare prices on different platforms (57.6\%); access to a wider range of goods that are limited or not represented in the domestic market (57.1\%); saving time (52.1\%).

At the same time, consumers of online stores more often buy clothes, shoes and accessories (56.7\%), cosmetics and perfumes (39.4\%) and appliances (33.3\%), due to the favorable offers of online stores for these goods, a wider range and increase in the total time spent at home.

The infographic of the results in Fig. 4 shows the results of the survey on the quality of services for ordering and delivery of goods, as well as determines the most commonly used methods of provision.

Thus, consumers equally often form their orders either on the official websites of stores, or in their absence on special online trading platforms, such as ROZETKA, OLX, PROM, Kasta $(69.3 \%)$, which have a wide range of different products. Such sites contain all the evaluation criteria that determine the consumer value for consumers. Buyers often order clothes, accessories and cosmetics through Instagram accounts. At the same time, delivery services as Glovo, Uber Eats, Raketa $(28.1 \%)$ have their network only in large cities and usually supply restaurants meals or food from supermarkets. 


\section{Benefits of online shopping}

Online price comparison Availability of a wide range Convenience, simple ordering process Customer reviews Time saving Unforeseen circumstances

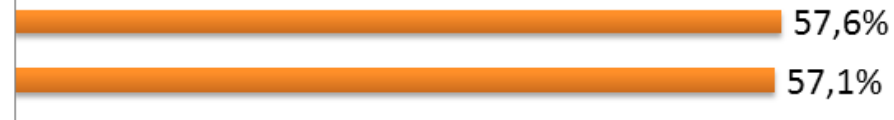
$5,6 \%$

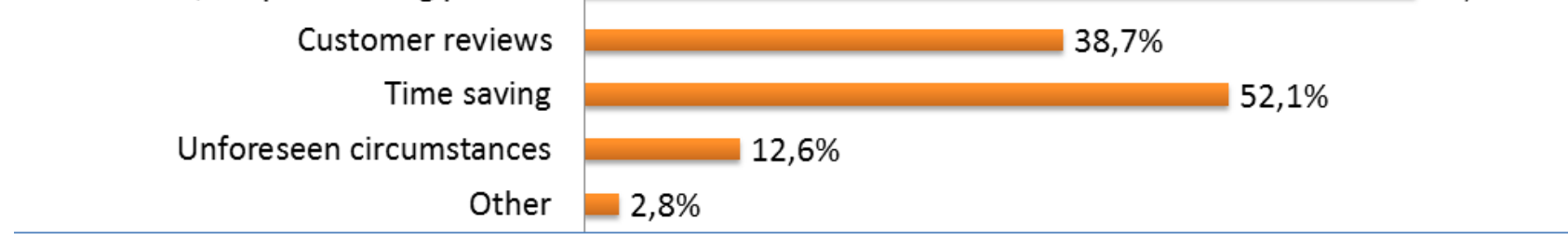

$2,8 \%$

\section{Nomenclature of goods}

Food

Household goods Household appliances Clothes, shoes, accessories Cosmetics, perfumes Children's items Stationery, books Food Delivery Medicine Services (TV, Music)

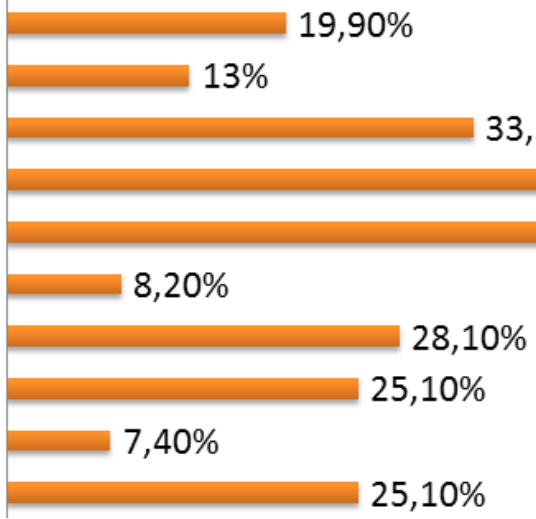

$56,70 \%$

$39,40 \%$

Online questionnaire

Figure 3. Infographics of online shopping during quarantine Complied and calculated by authors based on results of provided survey

According to the survey, most orders are picked up by buyers at the operator's post offices (84.9\%), the most popular of which is Nova Poshta, which delivers orders within Ukraine. UkrPoshta, Meest Express, DHL etc. deliver goods from abroad. Despite quarantine, the services of a postal operator courier $(30.6 \%)$ or a courier service such as Glovo, Uber Eats, Raketa (23.3\%) are used much less. 


\section{Online platforms for ordering}

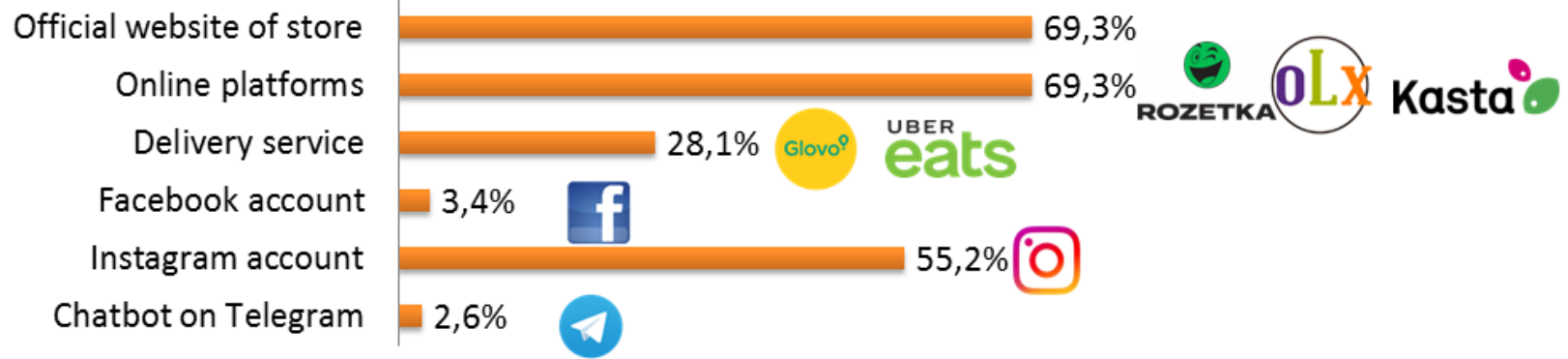

\section{Delivery of goods}

Courier delivery by the post office

Post office

Own courier service of store

Courier service

Difficult to answer $\quad 0,9 \%$
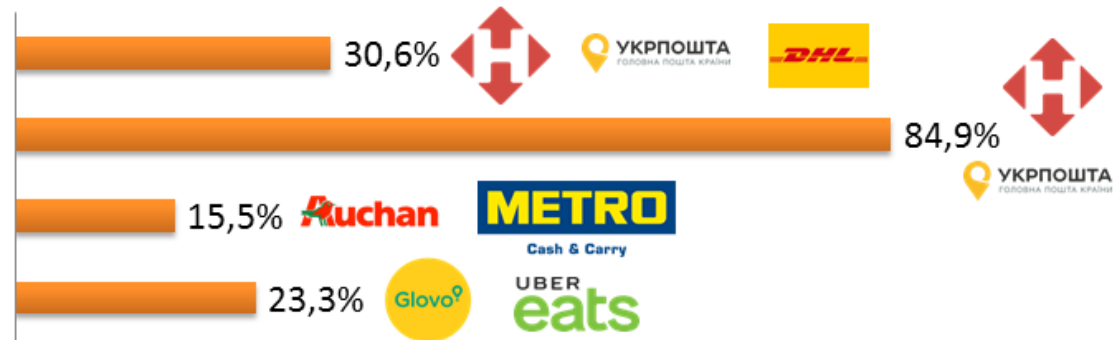

Online questionnaire

\section{Evaluative criteria for delivery of goods to the post office}

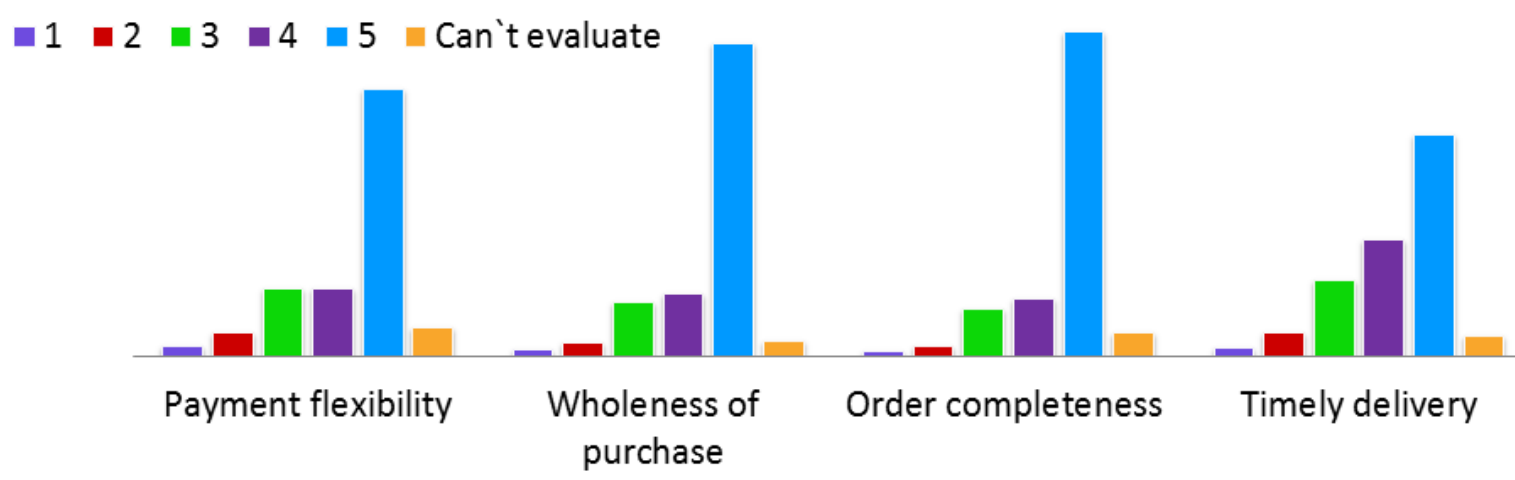

Evaluative criteria for courier delivery

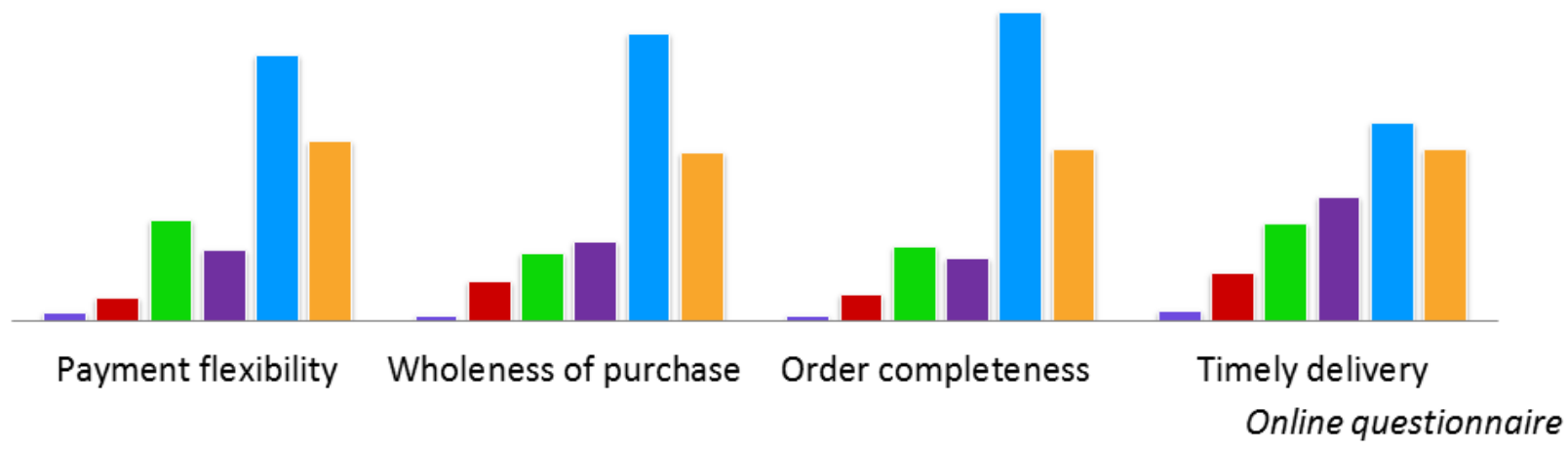

Fig.4. Infographics of the quality of online shopping logistics services Complied and calculated by authors based on results of provided survey 
Assessing the quality of work of the postal operator of the provided courier service, consumers said that they were satisfied with the delivery services and praised the presented criteria, but the most important among them were: completion of the order according to customer requirements, integrity of the purchase, namely product appearance in the process, and payment flexibility. At the same time, due to the pandemic, the demand for online shopping has increased, which has provoked full employment of staff, loading of all rolling stock and, consequently, reduced punctuality.

Conclusions. The marketing research was preceded by the author's survey study on the evaluation of the quality of logistics. Among the ten methods studied, the choice of the authors was focused on the method of SERVQUAL, from which 22 indicators were borrowed that characterize the quality of logistics, grouped by 5 features: material aspect; reliability; satisfaction of client's requirements; professionalism of employees; empathy and knowledge of customer needs. However, at the trial stage, the researchers faced the following problems: 1) some indicators were perceived ambiguously and needed further clarification (for example, from the group "material aspect of the service"); 2) some criteria were perceived as appropriate, and this should not be asked, but should be performed as best as possible (the group "empathy and knowledge of needs" was rejected); 3) some criteria, according to respondents, do not create added value to the consumer, so they were also excluded from the list. As a result, 22 indicators were reduced to 4: completeness, wholeness, flexibility and timeliness. And, - the criterium "safety" which provides observance of sanitary requirements (disinfection, use of protective suits, observance of social distance etc.) was added.

According to the results of the study, it is important for consumers to be able to independently choose additional delivery functions - place, time, delivery period, method of payment, which indicates the need to develop flexibility in the services of logistics operators. The modern consumer values his time, respectively, so the logistics service provider doesn't have the right to make a mistake in completing the order or improper storage of goods.

The transformation of the value of logistics services, according to respondents, concerns online interaction and speed of data exchange with the logistics service provider: contactless technologies, gadgets and applications that provide seamless online work, regardless of location. Online interaction, in particular online shopping, according to the study, attracts them with its simplicity $(69.7 \%)$, the ability to compare prices on different platforms (58.8\%), the availability of a wide range of goods $(57.5 \%)$ and saving time (52.9\%). Thus, the value of the benefits of digitalization increases. Those logistics providers that are more technologically advanced have a significant competitive advantage. E2E determine the value.

The obtained results change the understanding of the fullness of the quality of logistics evaluation criteria that are valuable for the target market, but do not solve the problem of measurability of the quality of logistics services, which will be the prospect of further research.

\section{References}

1. Kaplan J, Frias L, McFall-Jordan.(2020). A third of the global population is on coronavirus lockdown - here's our constantly updated list of countries locking down and opening up. Business Insider. URL: https://www.businessinsider.com/countries-on-lockdown-coronavirusitaly-2020-3 (Accessed April 2020) 
2. One in four retailers report "significant" supply chain issues due to coronavirus (2020). Logistics Express. URL: https://www.logistik-express.com/one-in-four-retailers-report-significantsupply-chain-issues-due-to-coronavirus/ (Accessed April 2020)

3. Симоненко, К. (2020). Тихіше їдеш, далі будеш: підсумки українського е-соmmerce i логістики за 2019-й. RAU Ukraine. URL: https://rau.ua/novyni/pidsumky-e-commerce-2019/ (Accessed April 2020)

4. Bank of America, U.S. Department of Commerce (2020). US E-commerce Penetration, ShawSpring Research 2020 (Accessed April 2020)

5. Krykavskyy, Ye., Pokhylchenko, O., Hayvanovysh, N. (2019). Digitalization of supply chains: new paradigm. 10th International Conference on Applied Economics Contemporary Issues in Economy, Torun, Poland, 27-28 June 2019 (Vol. 1). Institute of Economic Research, 103-108. DOI: $0.24136 /$ eep.proc.2019.4

6. Hryhorak M., Trushkina N., Tadeusz Popkowski, Molchanova K. (2020) "Digital transformations of logistics customer service business models". Intellectualization of logistics and Supply Chain Management. [Online], vol.1, p.57-75, available at: https://smartscm.org/en/journal-1-2020/hryhorak-mariia-trushkina-natalia-molchanova-kateryna-digitaltransformations-of-logistics-customer-service-business-models/ (Accessed 24 May 2020). DOI: https://doi.org/10.46783/smart-scm/2020-1-6.

7. World Bank (2018). LPI Country Score Card: Ukraine 2018. URL: https://lpi.worldbank.org/international/scorecard/radar/254/C/UKR/2018\#chartarea (Accessed April 2020)

8. Meffert, H., Bruhn, M., \& Hadwich, K. (2015). Dienstleistungsmarketing. Wiesbaden: Springer Fachmedien Wiesbaden.

9. Parasuraman, A., Zeithaml, V. A., \& Berry, L. L. (1985). A conceptual model of service quality and its implications for future research. Journal of marketing, 49(4), 41-50.

10. Bruhn, M. (2006). Qualitätsmanagement für Dienstleistungen. Springer Berlin Heidelberg.

11. Woźniak, J. (2017). Ocena przydatności metod SERVQUAL i CSI w kontekście badania logistycznej obsługi klienta. Przedsiębiorstwo we współczesnej gospodarce-teoria i praktyka, 21(2), 237-249.

12. Frąś, J. (2014). Wybrane instrumenty pomiaru jakości usług logistycznych. Zeszyty Naukowe Uniwersytetu Szczecińskiego, 803(6).

13. Nakonechna T., Kachmar R., Gryniv N., Danylovych T. (2019). Modeling of the retail pharmaceutical companies' customers service level // Contemporary issues in economy: abstract book of the 10th International conference on applied economics, 27-28 June 2019, Toruń, Poland, 193., DOI: 10.24136/eep.abs.2019.2 